\title{
Weapons Brushed By the Enemy: The Bounded Autonomy of Taiwan's Middle Power Foreign Policy
}

\author{
Kyong Jun Choi
}

This study investigates the bounded autonomy of middle power diplomacy by analyzing the continuity and changes in Taiwan's foreign policies. The case of Taiwan, which has emerged as a middle power through democratization and economic development, illustrates how the internal state of politics and the economy and the external state of security threats simultaneously constrain the foreign policies of middle power states. Democratization and economic development function not only as constraints on the foreign policy makers who deal with external security threats but also as a means to advance foreign policy in international politics. Establishing diplomatic ties with other countries and becoming a member of international organizations show how a country's foreign policy makers use material and normative policy tools to pursue their aims in international politics and how the interaction between internal and external conditions constrains the autonomy of foreign policy. The bounded autonomy of middle power states in dealing with great powers and security threats is primarily caused by the dual effects of democratization and economic development on the selection and use of foreign policy tools.

Key Words: Middle power diplomacy, Bounded autonomy, Democratization, Economic development, Taiwan

\section{INTRODUCTION}

After the Second World War, many newly independent states emerged in Asia, Africa, and South America, but few of these countries simultaneously accomplished democratization and economic development, while others failed

\footnotetext{
* Kyong Jun Choi (kjpol@jejunu.ac.kr) is an assistant professor in the Department of Social Studies Education, Jeju National University. He received a Ph.D. in political science from the University of Washington at Seattle. His primary academic interests have been comparative politics, international relations, and political sociology with a particular focus on the rule of law in new democracies and East Asian regional politics.
}

The Korean Journal of International Studies Vol.18, No.1 (April 2020), 87-122 
to accomplish either goal altogether. Only a handful extricated themselves from the mire of economic impoverishment. Contrary to expectations, as well, numerous nations that participated in the wave of democratization following the war suffered from democratic regression or reverted to authoritarianism.

Conversely, Taiwan achieved rapid economic growth after the 1960s and instituted a stable democracy after the late 1980s. Taiwan's example provided scholars with an opportunity to examine not only the conditions for successful political and economic development but also the characteristics of and the changes in the foreign policy of a country that evolved from a small power state into a middle power nation. The current work examines the case of Taiwan to identify the characteristics of a foreign policy implemented by a middle power, which has accomplished democratization and economic development, by focusing on the internal and external constraints and autonomy of the decision maker.

Independence, equality, and non-intervention in domestic affairs became the norm for international politics after the Westphalian system was established in Europe in 1648 (Gross 1948). In real international politics, however, great powers imposed constraints on, intervened in, and formed subordinate relations with weak powers because of imbalance in the power relations between countries. This reality gave rise to the anticipation that a change in status from being a weak power to a middle power will likely decrease external policy constraints and reinforce a state's autonomy. Nevertheless, although economic development and democratization create the momentum for a state to ascend to a position of moderate influence, they also limit the state's domestic autonomy, placing this nation under the dual influence of or interaction between internal and external constraints. Despite the existence of such restrictions, however, this study argues that democratization and economic development afford middle powers new diplomatic principles and measures that enable them to deal with great powers in international politics. The concept of bounded autonomy in the foreign policy of a middle power, as presented in this research, is aimed at overcoming the limitations of the existing "inside-out" and "outside-in" approaches that have been used to explain middle power diplomacy. It is also intended to identify the characteristics of autonomy and the internal and external constraints imposed on middle power diplomacy.

Through the case of Taiwan, this study aims to illuminate how a middle power can be established through democratization and economic development in an international environment characterized by security threats from neighboring great powers. In the Taiwanese context, this threat comes from China, which has significantly more material resources than Taiwan. Nonetheless, the latter extended tremendous efforts to compensate for its weaknesses by carrying out 
state-led industrialization and seeking policies oriented toward democratization to acquire a normative measure against such shortcomings. Deviating from the traditional perspective that a challenging security environment poses negative effects on political and economic development, Taiwan's emergence as a middle power reflects that security threats can also positively influence democratization and economic development, which in turn, function as Taiwan's powerful diplomatic tools in the international arena. Taiwan's diplomatic weapons have been unintendedly reinforced by its enemy across the strait. By delineating Taiwan's foreign policy as a middle power, this research intends to verify the effectiveness of economic growth and political development as a means by which to adopt material capabilities and norms as an instrument for pursuing diverse foreign policy goals, such as obtaining diplomatic recognition and membership in international organizations.

This study will further cast light on how the new internal and external policy constraints and policy instruments confronting an emerging middle power affect its diplomatic strategies and decisions. Policy makers in Taiwan are constrained not only by the country's domestic democratization but also by China's political circumstances. These issues compel the Taiwanese to frame policies designed to address challenges from China by considering the changing political situation in the Chinese context as regards its democratic progress and then adopting appropriate measures. They also face new policy restrictions both internally through the voices of dissenting domestic interest groups and externally through pressure from China, on which the Taiwanese economy is becoming increasingly dependent. Democratization and economic development have served as powerful instruments of diplomacy for the Taiwanese government, but they have also inhibited the autonomy of its foreign policy as a middle power. This bounded autonomy shows that under mutually interacting internal and external conditions, middle powers find ways to use various foreign policy instruments and that the decision makers implementing these policies display autonomy while also contending with limitations.

\section{THE MIDDLE POWER FOREIGN POLICY}

\section{A MIDDLE POWER AND ITS DIPLOMACY}

Scholars of international relations have focused on middle powers to explain the imbalance in the power of countries and the characteristics and roles of the foreign policy of states with varying degrees of power. However, without an agreed definition of a middle power, each scholar has presented a different 
definition, thus making the concept of middle powers even more vague and confusing. Cooper, Higgott, and Nossal (1993) provided five different concepts of a middle power differentiated by geographic, normative, positional, and behavioral approaches. Robertson (2017) posited that the traditional middle power could be classified by its location (sandwiched between two great powers), size (in between great and weak powers), and ideological position and political system (between two extremes).

These different conceptual categories of middle powers presented by these scholars show how the existing definitions of middle powers have incorporated objective conditions (e.g., geography and size), subjective characteristics (norms and perspectives), and policy actions (positions and behaviors) in international relations into the concept of a middle power, resulting in a jumbled concept consisting of the cause and effect of the foreign policy of a middle power. That is, the concept of a middle power includes the foreign policy actions taken by the country, which are the outcome (dependent variable), and the causes of such actions (independent variable). Thus, the concept loses its value and usefulness as an analytic tool for explaining the foreign policy of a middle power. If the independent and dependent variables combined in the middle power concept are not distinguished, discussions on middle power will be trapped in the tautology that "middle powers conducting middle power diplomacy because they are middle powers." To overcome such conceptual ambiguity, researchers should define the geographic conditions, size, power, and internal norms of a certain country as the origin of middle power diplomacy; analyze the resulting diplomatic strategies and actions or define the position and behaviors of a certain state as the characteristics displayed by a middle power; and search for the causes of such characteristics.

Among the various conditions of a middle power, including the size of its territory, geographic position, and characteristics of its political system, this study emphasizes the objective level of economic development (economic power) and the level of political development (democracy) as critical factors for analyzing the capacity and means of the middle power's diplomatic activities. A country's economic capacity is pivotal for establishing and maintaining the country's military power and is an important diplomatic means that can influence the international community through the amount of investment, aid, and international trade as well as the country's share of investment within international organizations. For a middle power under security threats from an authoritarian state, attaining the highest level of democratic institutionalization can also serve as a major means for gaining support from states, citizens, and international organizations advocating democracy, as major states and 
international organizations in the international community generally accept democratic values, such as freedom and human rights, as universal norms.

This study argues that a state's economic and political development levels, especially compared with those of other countries perceived as threatening the state, affect the state's choice of diplomatic means and their usefulness. A state with a higher economic and political development can use its material means of economic power and normative means of democratization as policy instruments to counter the threatening state in international relations. A state with a lower economic and political development is likely to have limits in using such means to counter a more developed state in these two dimensions. A state that has an advantage in either its economy or politics over the other state can use its relative strength to counter the state that poses a threat its national security.

\section{THE BOUNDED AUTONOMY OF FOREIGN POLICY}

Existing international relations literature on the link between international and domestic politics has mostly presented a one-way relationship through which the international or domestic sphere affects the other, with a focus on the limitations the policy maker experiences. In other words, existing literature maintains either the "outside-in approach," through which a state's foreign policy is determined by external factors including the international order or system (Waltz 1993; Keohane 1984), or the "inside-out approach," through which foreign policy is decided by internal factors such as the domestic political and economic conditions, including the coalitions of political and social forces, and the policy ideas shared by the elites and the public (Rogowski 1989; Hiscox 2001; Pepinsky 2008; Katzenstein 1996).

However, such one-directional approaches attest only to the constraints placed on the foreign policy makers and cannot be used in conducting a comprehensive analysis of the situation the policy maker, bounded by international and domestic influences, faces. These approaches are also vulnerable because the international variables of security threats and international systems and the domestic variables of democracy and economic development affect the decision-making process through their interaction.

For several decades, numerous historical sociologists, such as Tilly (1990), Hintze (1975), Downing (1988), and Lasswell (1997), have examined the effects of security environments on a state's domestic political and economic development. Although these studies have contributed to the further understanding of the domestic changes brought about by international politics, they either focus solely 
on the positive effects external security threats could have on the development of bureaucracy and the efficient economic management (Tilly 1990) or examine only the negative influence of the threats on democracy (Lasswell 1997). Existing research has limits in comprehensively identifying the positive and negative influences of external security threats on democracy and economic development. As shown in Table 1, external military threats or the existence of a strong foreign enemy simultaneously affects the democracy and economic development of a state in two different ways.

Table 1. Effects of Security Threats on the Formation of the Middle Power

\begin{tabular}{|c|c|c|}
\hline \multicolumn{3}{|c|}{$\begin{array}{l}\text { Security Threats } \\
\text { (Existence of Strong Enemy) }\end{array}$} \\
\hline$(+) \downarrow \downarrow(+)$ & \multicolumn{2}{|l|}{$(+) \downarrow \downarrow(+)$} \\
\hline $\begin{array}{c}\text { Material Power } \\
\text { (Economic Development) }\end{array}$ & \multicolumn{2}{|c|}{$\begin{array}{l}\text { Democracy } \\
\text { (Political Development) }\end{array}$} \\
\hline$\downarrow \downarrow \downarrow$ & & \\
\hline \multicolumn{3}{|c|}{$\begin{array}{l}\text { The Middle Power } \\
\text { (Material and Normative Power) }\end{array}$} \\
\hline
\end{tabular}

First, political development is positively and negatively affected by security threats. Having a strong external entity, especially an authoritarian state, as an enemy can motivate a state to present its democratization efforts to the international community to obtain approval for its international status or to secure foreign and international support. However, security threats may cause domestic militarization and encourage a state organization to grow excessively through violent means, such as through the military and the police, thus having a negative effect on democracy (Woo 2011).

Second, security threats have positive and negative effects on economic development. Military rivalries and conflicts with external powers necessitate and motivate economic development, which may be used to support a state's military power. However, the existence of a strong foreign enemy may encourage the state to focus immoderately on growing its military forces and to overinvest available resources in the military sector. In turn, the state may curb investment and profit gains in the non-military economic sectors, thus limiting its economic development (Deger and Smith 1983; Nolan 1986).

As an alternative model, this study presents the "bounded autonomy" approach based on the contributions and limitations of existing research in the fields of international relations and historical sociology on the link between international politics and domestic politics (Figure 1). The decision makers of 
foreign policy are bounded and yet autonomous within the external influence of the state's national security environment and the internal influence of democratization and economic development. According to this model, the external security environment affects domestic democratization and economic development because the policy makers' awareness of security threats affects their choice and implementation of domestic policy goals. Policy makers are not passive entities who are unilaterally controlled by the international structure but are active agents with bounded autonomy who could bring about structural changes by utilizing their available policy means to accomplish their own policy goals and who are constantly in search of new policy instruments.

Figure 1. Three Approaches to Middle Power Foreign Policy

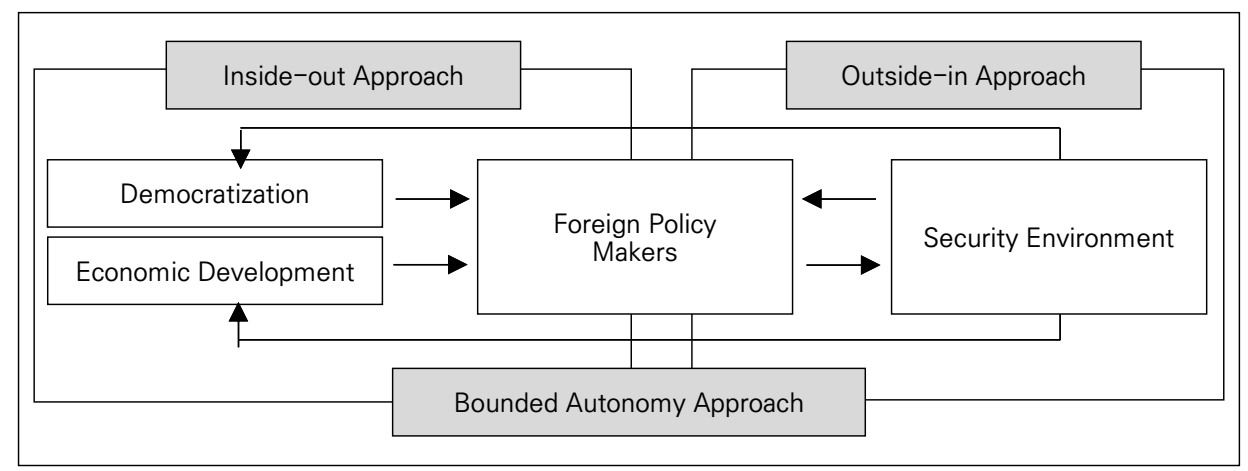

The case study of Taiwan presented in the following section shows how Taiwan became a middle power through democratization and economic development in its unusual security environment of overwhelming military threat from China and how such internal changes provided foreign policy decision makers with new foreign policy instruments and constraints. Through the analysis of Taiwan's utilization of foreign policy means for coping with military threat from China and dealing with the international community, this study identifies the characteristics of middle power foreign policy, which is bounded internally and externally.

\section{SECURITY ENVIRONMENT AND THE EMERGENCE OF TAIWAN AS A MIDDLE POWER}

After the Chinese Nationalist Party (Kuomintang, the KMT) decided to continue their battle against the communist regime and built a fortified state on the Island 
of Taiwan in 1949, Taiwan faced an overwhelming military threat from China. Thus, ensuring national survival was deemed urgent. This security situation forced Taiwan's ruling elites to make political decisions on issues of democracy and to create economic policies of state-led and export-oriented industrialization while living under a constant military threat from China. These decisions had negative and positive effects on Taiwan's political and economic development as the country grew into a middle power.

\section{SECURITY THREATS AND POLITICAL DEVELOPMENT}

The external military threat facing Taiwan had a negative effect on Taiwan's political development by bringing about internal militarization or, in other words, the formation of a garrison state. After entering the Island of Taiwan, the KMT suspended the constitution and imposed martial law on the entire territory. During Chiang Kai-Shek's authoritarian rule, the main goal was to restore military power and build a military base in Taiwan to fight the communist regime in the mainland. The goals of anti-communism and recovery of the mainland became the default national policy of the KMT regime (McBeath 1979, 163).

The national security crisis triggered by the threat from Communist China empowered the KMT regime to use the military and police forces, as well as other security organizations, as political means to ensure political security. The military confrontation with China and the international security crisis environment during the Cold War provided a strong justification for the KMT regime to stifle the political opposition. Domestic political resistance to the regime was easily stigmatized and then repressed as a treacherous act committed in collusion with the Chinese Communist Party in the mainland. The functions and roles of all state organizations in Taiwan reflected the KMT regime's deep concerns about national security. The security threat from China justified the Taiwanese government's creation and maintenance of strong coercive state organizations, which played comprehensive roles including the suppression of the democratic movement. Through these oppressive state organizations, the KMT government ensured the security of the regime (Martin, Chang and Yeh 2006, 231-233).

Paradoxically, however, the separation from the mainland and the security threat from China also had positive effects on the democratization of Taiwan. Although Taiwan met all the requirements needed for recognition as a sovereign state (e.g., national territory, stable political community of people, and solid government), the country faced a unique international quandary. Taiwan's state sovereignty was not recognized by the international community after the United Nations (UN) expelled the Republic of China (Taiwan) on October 25, 1971 (Martin 2014, 462). To restore its lost standing in the international community and to be 
recognized as a sovereign state, Taiwan took up the challenge of demonstrating the country's political advantages over China through democracy.

The need for the international community's recognition led the Taiwanese government to implement electoral democracy at the local level, albeit on a limited scale, even during the period of the authoritarian KMT regime. Although the suspension of the constitution led to a ban on almost all elections at the national level, which virtually guaranteed lifelong leadership roles to the representatives from the mainland elected before the 1949 defeat of the KMT, the KMT agreed to hold elections at the local level (Cha and Myers 1998). Elections to the posts of county magistrates and city mayors have been held since 1951 and the Taiwan Provincial Legislative Council elections since 1954. Thus, provinces existed as democratic islands in the sea of authoritarianism during the rule of the KMT regime. These democratic elements in domestic politics were part of an effort to show the contrast between the dictatorship of the Communist Party of China and the KMT government of Taiwan (Hughes 1997, 33, 50).

Needless to say, the democratic elections permitted at the local and provincial levels during the authoritarian period in Taiwan had limitations. The KMT exercised a considerable influence on the candidacy process to prevent local political powers from challenging the KMT regime. By making sure that there were always two political factions competing for KMT support in every county and city, the regime implemented a divide-and-rule strategy. Further, locally elected officials had a limited budget approval and minimal regulatory power. An institutional arrangement was also in place to ensure frequent power changes by allowing these officials only two terms (Mattlin 2011, 49).

However, despite these limitations, the electoral democracy at the local and provincial levels served as an important foundation for the transition to a full-fledged democracy in Taiwan in the late 1980s. Dangwei personalities, that is, non-KMT politicians, began to be elected to local government positions and organized themselves into the Democratic Progressive Party (DPP). The DPP, which triumphed in the 2000 and 2004 presidential elections and in the 2001 and 2004 legislative elections, began to compete with the KMT. Taiwan has grown into a democracy in which the two major political parties compete for seats in the state legislature. In the meantime, Taiwan witnessed three peaceful regime changes featuring the KMT and the DPP, thus demonstrating that the country's democracy, which is based on competitive party politics, is entering a stage of consolidation (Rigger 2014).

As shown in Figure 2, during the mid- and late 1980s, a huge divide emerged between Taiwan and China in terms of the level of democratization, which had been maintained at about the same level since the 1950s. To a great extent, the 
full-fledged democratization of Taiwan was the result of Taiwan's strategic endeavors and policies aimed at garnering the support and recognition of the international community by distinguishing the country from China. Although the democratization movement in China failed, the movement paradoxically contributed to the democratization of Taiwan. This result can be attributed to the pressure on the Taiwanese ruling elites to show the international community, especially the United States, that Taiwan was different from authoritarian China. The Tiananmen Square incident in China on June 4, 1989 pressured the KMT to show that it dealt with domestic political opposition in a better way than China (Wachman 1994, 227). The Taiwanese government found itself moving toward democratization to avoid being inconsistent: Taiwan realized that it was unable to support the student movement in China and criticize the Chinese government for oppressing it while oppressing the democratization movement in its own territory (deLisle 2014, 280-281).

Figure 2. Comparison of the Level of Democratization in Taiwan and China (1950-2013)

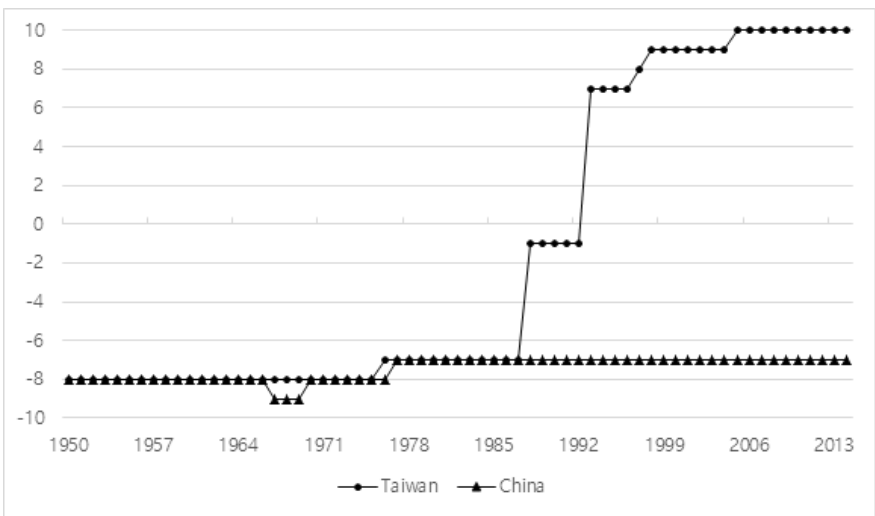

Source: The Polity IV data of Marshall and Gurr (2014).

The democratization-related political and strategic decisions made by policy makers in the context of cross-strait relations contributed to the democratization of Taiwan in a fairly peaceful and progressive manner through the top-down endeavors of Chiang Ching-Kuo and other ruling elites as well as their negotiation with the elites on the opposing side. After this successful democratization, Taiwan entered a stage marked by the consolidation of a democratic political system that clearly differentiated Taiwan from China. 


\section{SECURITY THREATS AND ECONOMIC DEVELOPMENT}

One of the negative effects of China's military threat on Taiwan's economic development is the country's excessive defense spending. A serious external military threat, especially in a security environment characterized by constant exposure to possible military attacks in the context of a divided nation, inevitably leads to excessive military spending. This expenditure reduces the resources for other economic sectors. It obstructs economic growth by causing decreases in the savings rate, restricting domestic and foreign investments in the private sector economy, and creating a quantitative and qualitative deterioration in capital stock (Deger and Smith 1983).

As shown in Table 2, Taiwan has an exorbitant defense budget to protect itself from China. Until the mid-1960s, Taiwan spent more than 10 percent of its gross domestic product (GDP) on defense. Although this defense-to-GDP ratio considerably decreased in the 2000s, the ratio was higher than that of China over the past few decades except in the mid-1990s. Until the early 2000s, Taiwan maintained a higher defense-to-GDP ratio than South Korea, which also expends significant resources on defense in the face of constant threats from North Korea. These figures demonstrate that Taiwan has recognized its security crisis as a serious problem and has allocated significant national resources for military expansion.

Table 2. Comparison of Defense Expenditures of Taiwan, China, and South Korea (Defense-to-GDP ratio, in \%)

\begin{tabular}{cccc}
\hline Year & Taiwan & China & South Korea \\
\hline 1955 & 10.4 & n.a. & 5.3 \\
1965 & 11.3 & n.a. & 2.4 \\
1970 & 8.7 & n.a. & 3.7 \\
1975 & 6.9 & n.a. & 3.4 \\
1980 & 8.0 & 5.4 & 4.3 \\
1985 & 6.6 & 2.9 & 5.2 \\
1990 & 5.4 & 3.1 & 4.4 \\
1995 & 5.0 & 5.7 & 3.4 \\
2000 & 5.6 & 3.9 & 2.8 \\
2005 & 2.2 & 1.3 & 2.6 \\
2010 & 2.0 & 1.3 & 2.4 \\
2015 & 1.9 & 1.2 & 2.4 \\
\hline
\end{tabular}

Source: IISS, The Military Balance (1987-2017).

However, despite the adverse effects of the security environment on economies, Taiwan's unstable security conditions have also brought about 
positive results in terms of economic development. The military threat from China has contributed positively to Taiwan's economic development by providing Taiwan with the motivation for economic development to reinforce its military capabilities against China, supplemented by policy measures that achieve rapid economic growth through state-led industrialization.

The KMT regime achieved economic development by promoting state-led industrialization based on the developmental state model during the 1960s1980s. Economic nationalism and the compelling need to catch up with the economically more powerful China made it possible for the KMT regime to establish a cooperative state-business relationship promoting export-led industrialization and rapid economic growth. Using the government-controlled allocation of resources, government intervention in the domestic economy and foreign trade, government-supported technology development, and efficient activities of public corporations, Taiwan was able to build a national economy with international competitive advantages within a short period of time (Wade 1990).

Taiwan's economic development can also be attributed to the country's adoption of export-oriented economic strategies and the United States' security policies against the communist bloc in the security environment of the Cold War era. Taiwan sustained a high rate of economic growth while maintaining its excessive defense spending because the country improved human capital, product quality, and commercial adaptability by successfully competing in the global market based on its export-oriented economic strategies (Chan 1988, 918919). Indispensable for the success of Taiwan's export-oriented policy was the United States' role in the Cold War security environment. The security interests of the United States in blocking the expansion of communism in East Asia led the country to adopt trade policies, such as opening its domestic market to Taiwan and absorbing Taiwan's exports, which was favorable to Taiwan. This policy helped Taiwan achieve its state-led, export-oriented industrialization (Pempel 1999). As a result, Taiwan has attained high economic performance in terms of the economic growth rate, total GDP, per-capita income, and growth in merchandise trade as shown in Table 3. 
Table 3. Taiwan's Economic Indicators

\begin{tabular}{|c|c|c|c|c|c|c|c|}
\hline \multirow[b]{2}{*}{ Year } & \multicolumn{3}{|c|}{ GDP } & \multicolumn{3}{|c|}{ Merchandise Trade in US\$ Million } & \multirow{2}{*}{$\begin{array}{l}\text { Foreign Exchange } \\
\text { Holdings of Central } \\
\text { Bank of ROC in } \\
\text { US } \$ \text { Million }\end{array}$} \\
\hline & $\begin{array}{c}\text { Economic } \\
\text { Growth Rate } \\
\text { (\%) }\end{array}$ & $\begin{array}{l}\text { GDP in US\$ } \\
\text { Million at } \\
\text { Current Prices }\end{array}$ & $\begin{array}{c}\text { Per Capita } \\
\text { GDP } \\
\text { (US\$) }\end{array}$ & Exports & Imports & Balance & \\
\hline 1955 & 7.7 & 1,940 & 216 & 123 & 201 & -78 & $\mathrm{n} / \mathrm{a}$ \\
\hline 1960 & 7.2 & 1,743 & 163 & 164 & 297 & -133 & $\mathrm{n} / \mathrm{a}$ \\
\hline 1965 & 11.9 & 2,869 & 229 & 450 & 556 & -106 & 245 \\
\hline 1970 & 11.5 & 5,786 & 397 & 1,481 & 1,524 & -43 & 482 \\
\hline 1975 & 6.2 & 15,838 & 985 & 5,309 & 5,952 & -643 & 1,074 \\
\hline 1980 & 8.0 & 42,295 & 2,389 & 19,811 & 19,733 & 77 & 2,205 \\
\hline 1985 & 4.8 & 63,623 & 3,315 & 30,726 & 20,102 & 10,624 & 22,556 \\
\hline 1990 & 5.7 & 166,615 & 8,216 & 67,214 & 54,716 & 12,498 & 72,441 \\
\hline 1995 & 6.5 & 279,224 & 13,129 & 113,342 & 104,012 & 9,330 & 90,310 \\
\hline 2000 & 6.4 & 331,452 & 14,941 & 151,950 & 140,732 & 11,218 & 106,742 \\
\hline 2005 & 5.4 & 375,769 & 16,532 & 199,761 & 185,438 & 14,323 & 253,290 \\
\hline 2010 & 10.6 & 446,105 & 19,278 & 278,008 & 256,274 & 21,734 & 382,005 \\
\hline 2015 & 0.8 & 525,562 & 22,400 & 285,344 & 237,219 & 48,124 & 426,031 \\
\hline
\end{tabular}

Source: National Development Council, Republic of China (2019), pp. 19-21.

To sum up, despite the adverse effects of the division and the security threat from China on Taiwan's politics and economy, Taiwan has achieved democratization and economic development. The need to strengthen the country's material capabilities to be "militarily similar to China" positively contributed to Taiwan's economic development, and the strategic need to be "politically dissimilar to China" to gain the support of the international community by differentiating itself from China contributed to Taiwan's democratic advancement and institutionalization.

\section{TAIWAN'S FOREIGN POLICY FOR DIPLOMATIC RECOGNITION}

\section{CRISIS IN DIPLOMATIC RECOGNITION}

From 1949 to the beginning of the 1960s, Taiwan's foreign policy revolved around increasing the country's anti-communist allies, improving its relations with the United States, preventing China from joining the UN, and forestalling countries that maintained diplomatic relations with Taiwan from switching positions and recognizing China instead. Taiwan tried to convince the international community that it was the sole legitimate government of the Chinese nation. As 
soon as the communist government was established in China, all communist countries granted China diplomatic recognition. However, only a few non-communist countries recognized China. This stance by the non-communist countries can be ascribed to the generally hostile attitude toward China because of its involvement in the Korean War and the Cold War and the United States' anti-communist policy toward China. In this atmosphere, Taiwan maintained its status as the legitimate representative of the Chinese nation with the support of the majority of the UN nations until 1971 (Wang 1990, 3-4).

However, in the 1970s, Taiwan faced a serious diplomatic crisis. As shown in Table 4, the number of countries maintaining diplomatic relations with Taiwan fell sharply during this decade from 71 in 1970 to 24 in 1979, whereas the number of countries establishing diplomatic relations with China significantly increased from 48 in 1970 to 117 in 1979. This result was partly caused by Taiwan's rigid policy of defining countries entering into diplomatic relations with China as hostile countries and cutting official ties with them in accordance with the slogan "not living together with the Communist regime under the same sky." By contrast, China attracted many countries as diplomatic partners by moving away from the rigid diplomacy of aggressive principles, such as "anti-Western imperialism," "anti-capitalism," and "international communist revolution," and steering toward flexible and practical diplomatic strategies. As a result, Taiwan lost its status in the UN in 1971. Japan and the United States established diplomatic relations with China in 1972 and 1978, respectively, thus ending their recognition of Taiwan (Wang 1990, 8-10).

Table 4. Changes in the Number of Countries that Have Official Diplomatic Relations with Taiwan or China

\begin{tabular}{ccc}
\hline & Taiwan & China \\
\hline 1970 & 71 & 48 \\
\hline 1973 & 39 & 84 \\
\hline 1979 & 24 & 117 \\
\hline
\end{tabular}

Source: Wang (1990, 7-8).

Taiwan's diplomatic presence in the international community continued to decline. Taiwan could not become a member of international organizations, the membership of which is based on state sovereignty, because of its loss of a UN seat and China's adherence to the "One China" policy. Although most major powers other than China had established unofficial relations with Taiwan, Taiwan's officials faced restrictions in interacting with high-ranking foreign officials during their official visits to foreign countries, finding themselves in an 
unusual position of maintaining only unofficial relations via de facto foreign representatives, such as the Taipei Economic and Cultural Representative Office in the United States and the American Institute in Taiwan (Chen 2016, 41).

With a large number of countries breaking off diplomatic ties with Taiwan within a short period, Taiwan attempted policy changes to prevent further losses and actively sought out diplomatic ties. It moved away from its rigid diplomatic approach, which had triggered countries to end their recognition of Taiwan and enter into ties with China in the 1970s, and took the stance that the country could maintain diplomatic relations, or establish new diplomatic relations, with countries that had established diplomatic relations with China. However, this policy change could not set back the trend of switching diplomatic partners from Taiwan to China (Hughes 1994, 54-55).

\section{MATERIAL AND NORMATIVE MEANS FOR SECURING DIPLOMATIC SUPPORT}

To compensate for the vulnerability arising from the lack of diplomatic recognition in the international community, Taiwan used a strategy of building economic relations with potential and actual diplomatic allies. Taiwan's economic success has provided the country with an important instrument of foreign policy. When the communist regimes in Eastern Europe and the former Soviet Union fell, Taiwan approached the former communist countries, which needed foreign investment and aid, as new targets for expanding the country's range of diplomatic ties by using economic power as a weapon (Tubilewicz 2004). In the late 1980s and early 1990s, Taiwan gave large-scale foreign aid to former communist countries. Many countries, such as Hungary and Poland, opened offices in Taipei to carry out official operations informally (Lee 1993, 47-48).

The Taiwanese government further intensified its efforts to prevent diplomatic isolation and expand its diplomatic influence through active donations not only to individual countries in Asia, Africa, and Latin America but also to various international organizations. Taiwan offered international aid to maintain partnerships or to convince states to break off relations with China, a practice referred to as "dollar diplomacy" (Rich 2019). For example, in the summer of 1988, the Taiwanese government raised a US\$ 10 billion development fund for the development of Third World nations (Wang 1990, 10-11). In 1991, the government donated the US\$ 150 million "Fund for the Economic and Social Development of Central America" to the Central American Bank for Economic Development to obtain membership in the bank in return. This endeavor enabled Taiwan to establish diplomatic relations with the Bahamas, Belize, Grenada, Nicaragua, Central African Republic, Liberia, and Niger (Lee 1993, 47-48). To sustain its 
relationship with its diplomatic allies, especially those in Central America, Taiwan also provided military assistance, investment, and even donations of weaponry and aircraft to countries with which it maintained formal relations (Rich and Dahmer 2018).

However, Taiwan's official development assistance became limited because of its lack of recognition of sovereignty from the international realm. As Table 5 illustrates, the amounts Taiwan provided each year for official development assistance have remained between 271 and 381 million dollars since the 2010s, which is equivalent to only 0.05 to 0.1 percent of Taiwan's gross national income (GNI), falling far short of the UN standards of 0.7 percent. The low ratio of Taiwan's Official Development Assistance (ODA) in the GNI can be partly explained by its inability to provide the ODA in the form of multilateral aid. For example, in 2008, bilateral aid accounted for 92 percent, and the remaining 8 percent took the form of multilateral aid. As Taiwan is not recognized as a sovereign state, international organizations, such as the World Health Organization (WHO), have rejected donation from Taiwan, which had to donate indirectly through other foreign institutions without specifying its country name as a donor country. As a result, Taiwan's ODA has been mainly concentrated on countries that recognize Taiwan's sovereignty. The Taiwanese government has officially announced that its development assistance is a way to "promote partnerships for progress with Taiwan's diplomatic allies and friendly countries" and to consolidate the bilateral relations between Taiwan and these countries even further (Ministry of Foreign Affairs of Republic of China 2009, 27-41).

Table 5. Taiwan's Official Development Assistance

\begin{tabular}{ccccccccccc}
\hline Year & 2009 & 2010 & 2011 & 2012 & 2013 & 2014 & 2015 & 2016 & 2017 & 2018 \\
\hline Total Amount & 411 & 380 & 381 & 304 & 271 & 273 & 277 & 327 & 310 & 301 \\
$\%$ of GNI* & 0.130 & 0.101 & 0.093 & 0.061 & 0.054 & 0.050 & 0.052 & 0.060 & 0.054 & 0.051 \\
\hline
\end{tabular}

Source: National Development Council, Republic of China (2012-2019).

* GNI means gross national income.

Gradually, Taiwan's dollar diplomacy became even more limited as China's economic power far surpassed that of Taiwan. The limitation of using economic power for diplomatic recognition became clear as the number of Taiwan's diplomatic allies further shrunk. Since the election of president Tsai Ing-wen in 2016, Taiwan has lost seven allies (Sao Tome and Principe, Panama, Burkina Faso, the Dominican Republic, El Salvador, the Solomon Islands, and Kiribati), and as of October 16, 2019, those who still recognize Taiwan are one in Africa, one in Europe, nine in Latin America and the Caribbean, and four in the Pacific, as 
shown in Table 6 (Lyons 2019; Rich 2019; Chen 2019).

Table 6. The 15 Countries that Maintain Diplomatic Relations with Taiwan

\begin{tabular}{ll}
\hline \multicolumn{1}{c}{ Region } & \multicolumn{1}{c}{ Country } \\
\hline Africa & Eswatini (former Swaziland) \\
Europe & The Holy See (Vatican) \\
Latin America and the Caribbean & $\begin{array}{l}\text { Belize, Guatemala, Haiti, Honduras, Nicaragua, Paraguay, Saint Kitts } \\
\text { and Nevis, Saint Lucia, Saint Vincent and the Grenadines } \\
\text { The Pacific }\end{array}$ \\
\hline
\end{tabular}

Source: Chen (2019).

China has increased its efforts to isolate Taiwan diplomatically by utilizing aggressive money diplomacy, which raises a primary challenge to Taiwan. Taiwanese offers of international assistance are unlikely to be enough to avoid losses of its diplomatic allies now that China is willing to offer larger and broader assistance packages than those Taiwan had traditionally provided. China reportedly offered US $\$ 500$ million to lure the Solomon Islands into making a switch in 2019 (Chen 2019). A subsidiary of China Railway Group signed a US\$ 825 million contract with the Solomon Islands for a gold-mining project on the same day the country switched its recognition policy (Myers and Horton 2019). China also offered Kiribati US\$ 500 million in assistance to purchase commercial airplanes after Taiwan rejected the request from Kiribati for a large amount of financial assistance from Taiwan to purchase commercial airplanes (Rich 2019; Wen 2019; Myers and Horton 2019).

Witnessing the shortcomings of using material power to compete with China for diplomatic recognition, Taiwan has sought to utilize normative means of foreign policy. When the Solomon Islands and Kiribati switched their diplomatic ties to China, Taiwan's Ministry of Foreign Affairs (MOFA) claimed that "China's suppression of Taiwan in the international arena cannot change the indisputable fact of Taiwan's existence nor it coerce the Taiwanese people into abandoning their democratic and free way of life" (Myers and Horton 2019). Taiwan tries to strengthen its appeal to other countries through democratic values to fortify its national security by gaining the support of the international community. Policy makers in Taiwan strive to actively apply their diplomatic strategy of using democratic norms as a foreign policy instrument based on domestic democratization to the country's diplomatic relations, especially with the United States and Western countries.

On March 26, 2019, in Hawaii, President Tsai pointed out that China's malign influence was visible everywhere in the world, but the presence of the United 
States was generally missing. Further, she urged the United States to be vigilant against the threat posed by China's massive efforts to infiltrate, undermine, and eventually abolish Taiwan's democracy (Rogin 2019). On July 12, 2019, in her speech at Columbia University, President Tsai emphasized again the importance of Taiwan as a democratic country and the necessity of the international society to support a "free and democratic Taiwan" to contain the growing threats from authoritarian forces. She said that Taiwan's survival involves more than just cross-strait relations because it has been a vital bastion of democracy in the Indo-Pacific region (Yang and Chin 2019, 1). As her series of speech illustrates, Taiwanese foreign policy makers utilize their accomplishment of democratization as a foreign policy tool to secure international support and cope with the threat from China.

\section{TAIWAN'S MEMBERSHIP DIPLOMACY AS A MIDDLE POWER}

\section{ENDEAVORS FOR MEMBERSHIP DIPLOMACY}

While facing a crisis in maintaining diplomatic relations with individual countries, Taiwan was keen to join and participate in international organizations. Taiwan's interest was not limited to intergovernmental organizations (IGOs), in which only a sovereign state could participate, but also included international non-government organizations (INGOs), which admit non-states as members. Taiwan is a full member of the World Trade Organization (WTO), the Asia-Pacific Economic Cooperation (APEC) forum, and the Asian Development Bank (ADB). It also holds an observer status in the WHO and participates in about 30 INGOs (Chen 2016, 42; Hughes 1997, 49). The process of Taiwan's affiliation in these international organizations illustrates the uses and limitations of using material and normative means as foreign policy tools for extending its international space.

Although Taiwan was one of the original members of the General Agreement on Tariffs and Trade (GATT) as the Republic of China, it was downgraded to observer status in 1965 before fully withdrawing from the agreement in 1971 (Lin 2018). As Taiwan's economy grew to become the world's thirteenth-largest trading nation, it attempted to re-join GATT by submitting its application to the secretary general of GATT in 1990. GATT established a working group in September 1992 to formally review Taiwan's application for membership, and on January 1, 2002, the WTO, which had replaced GATT in 1995, decided to grant full membership to Taiwan under the title of "the Separate Customs Territory of Taiwan, Penghu, Kinmen, and Matsu (Chinese Taipei) (Winkler 2014, 248).

This incident marked the first occasion since Taiwan withdrew from the UN 
in the 1970s that it had overcome all obstacles to become a formal member of a multilateral international organization (Lin 2018). Taiwan implemented profound economic changes to gain entry into the WTO. Starting in 1990s, large-scale liberalization reforms were carried out, and thus the private sector gradually took the place of state-run enterprises to become the main engine of economic growth under the market mechanism. At the same time, improper and excessive regulations were re-examined and loosened, and transparency and due process came to be respected (Taiwan Today 2012). However, Taiwan's entry into the WTO became possible partly because China had not been an existing member of the WTO. China, which also sought its own membership, agreed not to block if Taiwan would be affiliated as "Chinese Taipei” (Olson 2001).

Taiwan also resumed its efforts to restore the WHO membership it had lost in 1972. As WHO is a specialized agency of the UN, the membership of which is granted only to sovereign states, Taiwan's accession to WHO was an issue closely related to the country's sovereignty. From 1997 onward, Taiwan repeatedly applied to participate as an observer at the World Health Assembly (WHA), the high-level meeting of the WHO, but was refused each time. The membership application document submitted in 2007 by the Chen Shui-Bian administration was not even accepted. In 2008, the Ma Ying-Jeou government applied to participate as an observer under the title "Chinese Taipei" instead of Taiwan and was finally granted the observer status in the WHA (Winkler 2014, 250-256). The DPP criticized Ma for using an inferior title and downgrading "Taiwan sovereignty" and claimed that he had paid too high a price for Taiwan's "sovereignty, security, democracy, and economic leverage" for a dubious gain (deLisle 2009; Huang 2019).

Although Taiwan's admission to the WHA as an observer provided Taiwan access to the WHO information on the outbreak and global response measures, its status was still not official and remained contingent on annual invitations. A secret 2005 memorandum between the WHO and China reportedly required that all that must contact Taiwan, such as for inviting Taiwan to participate in activities and exchange information, should first pass through China (Tiezzi 2014; Glaser 2013, 17). The Taiwanese government argued that "due to China's suppression, between 2009 and 2019, Taiwanese experts received invitations to only 49 of 165 meetings for which they had applied, representing a rejection rate of 70 percent" (Bureau de Genève, Délégation Culturelle et Économique de Taipei 2019).

Taiwan's holding of an observer status at the WHA became short lived. It was able to participate at annual WHA events as an observer only between 2009 and 2016 because it had not received an invitation since its last attendance in May 2016 (Aspinwall 2019; Huang 2019). In 2017, China blocked the WHO from issuing 
Taiwan an invitation to attend the 70th WHA meeting as an observer (Lawrence and Morrison 2017, 59). When Taiwan was blocked from participating at the WHA, President Tsai remarked, "Taiwan should not be excluded from WHA this year for any reason. Health issues do not stop at the border, and Taiwan's role is important to global health" (Smith 2017).

As Taiwan's participation in the WHA continued to be blocked because of China's interference, the Taiwanese government intensified its blaming of China and asked for support from international society. In 2019, Taiwan's MOFA urged the world to recognize the malevolent nature of the Chinese government and support the inalienable rights of the Taiwanese people to take part in international organizations. It argued the following: "If international agencies continue to comply with Chinese coercion to reject the Taiwanese people, it will encourage the Chinese government's callousness to grow further to the detriment of the entire world" (Bureau de Genève, Délégation Culturelle et Économique de Taipei 2019). According to Taiwan's foreign minister, Taiwan's exclusion from the assembly was "morally wrong," and the move left Taiwan more vulnerable to pandemics and denied the nation the opportunity to share its own healthcare advances with the rest of the world (Aspinwall 2019). President Tsai remarked, "Regardless, we remain committed to contributing to global health security" (Teng 2019b).

\section{EFFICACY AND LIMITATION OF USING MATERIAL POWER}

Taiwan tried to use its economic power to obtain membership in international organizations. However, its dollar diplomacy to broaden its international space encountered some drawbacks. As China's economic and political clout increases, China outpaces Taiwan in both ability to give and amount given. Taiwan's room to move to engage in dollar diplomacy is becoming more restricted (Rich and Dahmer 2018).

In 2014, the Taiwan government prepared to donate US $\$ 1$ million to the WHO, but the organization refused it. In the end, the government made the donation through a foundation under the US Centers for Disease Control and Prevention, and the donation receipt identified an American foundation as the donor without mentioning Taiwan. In May 2018, the Taiwanese government announced another plan to donate US\$ 1 million to the WHO to fund the fight against the Ebola virus. However, the WHO failed to come up with proper arrangements on the donation from the Taiwan government because of "political consideration" about specifying the donor name. Taiwan expected to make the donation in the name of "Republic of China" (ROC), the official name of Taiwan. However, the donation plan was suspended because the negotiation with the WHO failed to reach a consensus (Teng 2018; Lin 2019). The MOFA of Taiwan announced that despite 
being compelled to suspend this donation, "Taiwan will continue to participate in international cooperation on disease prevention and remains firmly committed to making concrete contributions" and would show the world that the people of Taiwan set no limits in their humanitarian engagement (Ministry of Foreign Affairs 2019).

The limited economic power of Taiwan vis-à-vis China in international organizations is also shown by its shares in the ADB. In 1966, while still recognized by the UN as the government of China, Taiwan as the ROC was one of the 31 founding members of the ADB. When China joined the bank in 1986, Taiwan's membership was continued with the designation "Taipei, China" (Courtenay 2006). As of 2018, China has 684,000 shares (6.4 percent), whereas Taiwan only has 115,620 shares (1.0 percent). Therefore, Taiwan's voting strength is only about 15 percent of that of China. As of December 31, 2018, Taiwan has contributed US $\$ 1.61$ billion in capital subscription and US $\$ 122.26$ million to the Special Funds since joining in 1966. Conversely, China has contributed US\$9.51 billion in capital subscription and US\$212.6 million to the Special Funds since 1986 (Asian Development Bank 2019).

Taiwan has tried to overcome its limited involvement in international organizations by joining regional organizations, such as the APEC, which Taiwan joined in 1991, two years after it was established in 1989. Taiwan's acceptance into the organization was the combined result of the internal policy of the organization and China's domestic problem. From the start, the APEC was composed of "economies" rather than sovereign states. This provided a favorable condition to Taiwan, which lacks the status of a sovereign state. Furthermore, not yet a member of APEC itself, China's ability to thwart Taiwan's membership was limited. China's diplomatic isolation after the 1989 Tiananmen Square crackdown also worked in Taiwan's favor. After negotiations with China, Taiwan successfully joined the APEC as a full member under the name of "Chinese Taipei," alongside China in 1991 (Glaser 2013, 25-26).

Although all of the economies in APEC are considered equal to one another, Taiwan has one other major condition tethered to its membership. China insisted that the Taiwan president should not take part in the gathering. Accordingly, Taiwan's president does not participate in the APEC's annual economic leaders' meetings, and since the gathering in 1993, Taiwan has been represented each year by a lower-level or formal government official or a prominent private citizen (Horton 2017; Lawrence and Morrison 2017, 61).

However, for Taiwan, the APEC is much more than a regional forum because it provides a valuable platform for Taiwanese officials to interact directly with the governments of important developed and developing countries, including 
China. Taiwan's participation in APEC is important for enhancing the country's international image and status. The Taiwanese government interprets its participation in the APEC as its contribution to regional development. On October 14, 2019, President Tsai remarked that the task of Taiwan in the APEC is to make Taiwan's dedication to promoting inclusive and sustainable growth known to international partners and to join other economies in enhancing economic growth for the Asia-Pacific region in an inclusive and sustainable manner (Yeh and Lim 2019).

Taiwan's endeavors to participate in international organizations illustrate that its strategy of using its economic power as an instrument for foreign policy is not merely "silver bullet diplomacy" based on material superiority. Taiwan tries to emphasize its role in and contribution to the international community as a global trading power and a technologically advanced economy. Taiwan seeks to build a self-image of a responsible cooperator that attaches great value to market economy, transparency, rule of law, and intellectual property rights in a globalized economy based on liberalism that goes beyond a simple quantity-driven economy. In doing so, Taiwan tries to create a contrast between itself and China and emphasizes that it has more in common with the United States and other advanced countries. When Taiwan attempted repeatedly to join the WTO, the country stressed that, unlike China, it respected and observed the GATT rules and liberal economic principles. In this manner, Taiwan conveyed the message that the country, a top twenty trading entity that met or surpassed many members' compliance with the WTO rules, is an appealing country worthy of acceptance in the international community (deLisle 2009; deLisle 2014, 276-277).

\section{SEEKING FOR THE USE OF NORMATIVE POWER}

Democratization is also an important diplomatic means for Taiwan to enhance the recognition of its ideological and normative legitimacy in the international community and to enlarge its international space. While dealing with the international community, Taiwan has distinguished itself from the authoritarian state on the other side of the strait by showing that the value and power of Taiwan's success in achieving full-fledged democratization stand in stark contrast to mainland China's steady authoritarianism (Horowitz and Tan 2007, 124). China's diplomatic capacities in the normative aspects has decreased as the international community's criticism of China's brutal military crackdown on pro-democracy protests, as shown in the 1989 Tiananmen Square incident in China, has increased. By contrast, Taiwan has improved its image in the international community as a country on the verge of a democratic transition unlike China (Wang 1990, 11). 
Taiwan has actively used its democratic achievements as an instrument for implementing its foreign policy. It has used a strategy of emphasizing the importance of the country's participation in ensuring the efficient operation of a core international regime for human rights and its contribution to promoting the widely shared goals and values of the international community, such as freedom, liberty, and rule of law. How Taiwan utilizes the strategy of using normative means has been shown by its efforts to join the International Covenant on Civil and Political Rights (ICCPR) and the International Covenant on Economic, Social and Cultural Rights (ICESCR), which, together with the Universal Declaration of Human Rights, are the three most important global human rights agreements. Although its efforts were not successful in obtaining formal international recognition, Taiwan has shown effort in putting these covenants into practice (deLisle 2014, 278).

On March 31, 2009, the Taiwanese legislature ratified the ICCPR and the ICESCR, giving the two international covenants legally binding force in Taiwan. After ratifying the two covenants, the Taiwanese government sent them to the UN secretariat. Although Taiwan signed these two covenants in 1967, the process of ratification and depositing the covenants into the custody of the UN Secretariat faced various internal obstacles, including the attitude of Taiwan's former authoritarian government, and was not completed until 2009. The legislature not only approved the covenants but also passed a law on their implementation, clearly ruling that they would have legal effect domestically whether they were deposited with the UN or not. The implementation law calls for the forming of a national human rights reporting system to regularly monitor the implementation of covenants. It also states that government agencies should protect human rights and assign the responsibility of reviewing and amending the existing laws and practices to government bodies at all levels (Huang 2009; Wang 2009). The Taiwanese government also promulgated the Enforcement Act of Convention on the Elimination of All Forms of Discrimination against Women in 2011 and implemented the Act of the Convention on the Rights of the Child in 2014 (Taiwan Today 2015).

To demonstrate its efforts in protecting human rights in the face of the international community, Taiwan released a report on its implementation of the ICCPR and ICESCR in April 2013. When the report was released, President Ma praised Taiwan's efforts for upholding human rights: "We see the protection of human rights as an established worldwide trend. The impact of the various international human rights covenants is steadily expanding, so human rights issues no longer fall strictly within the ambit of a nation's internal affairs. If the mainland authorities recognize this fact, then they should ratify the ICCPR as 
soon as possible.” He also distinguished between democratic Taiwan and authoritarian China by emphasizing that "a gap in the quality of human rights protections on the two sides has long impeded efforts to lessen the feeling of 'otherness' between people on the two sides of the Taiwan Strait" (Taiwan Today 2013). In December 2015, the Presidential Office spokesman announced the following: "As per Article 141 of the constitution, the ROC is a country that respects treaties and the UN Charter in order to promote international cooperation, advance international justice, and ensure world peace" (Taiwan Today 2015).

By making such efforts, Taiwan tried to let the world know that it was complying with and implementing international rules and norms as a democratic country. Further, Taiwan's attempt to actively participate in as many international organizations as possible reinforced the country's image as a member of the international community eager to cooperate with others, support international institutions, and partake in the burden of the international community for upholding a free and liberal international order (deLisle 2014, 278). In pursuing foreign policy goals, Taiwan has always emphasized its position as a supporter of the rules and norms of the international community in terms of human rights, freedom, and liberty and as a defender of its systems in contrast to China, which adopts an unappealing and threatening approach to international affairs. In 2019, when Taiwan was unable to participate in WHA, Taiwan's MOFA announced that "Taiwan is internationally celebrated as a beacon of freedom, democracy, and human rights. The country has never been governed by Beijing or fallen under its jurisdiction." It also claimed that "Only the democratically elected government of Taiwan can represent the people and the country in international organizations" and that "this will never change, irrespective of bullying and the ongoing campaign of coercion from the other side of the Taiwan Strait” (Taiwan Today 2019).

Although Taiwan encountered some limitations and frustrations in its membership diplomacy, its efforts to participate in and accede to IGOs and INGOs became possible because the country grew into a middle power through democratization and economic development. The country's material and normative power, which had enabled the country to rise as a middle power, provided Taiwan new policy instruments necessary for pursuing its foreign policy.

\section{INSTRUMENTS AND CONSTRAINTS OF A MIDDLE POWER FOREIGN POLICY}

VARIETIES OF MIDDLE POWER DIPLOMACY AND POLITICAL CONSTRAINTS The growth of Taiwan as a middle power with democracy and a developed 
economic system based on liberal market economies has made it possible to employ varieties of foreign policy, such as co-optive diplomacy, counternormative diplomacy, benefit-sharing diplomacy, and universal normative diplomacy, as shown in Table 7. Although these four different types of foreign policies pursued by Taiwan since its emergence as a middle power vary depending on the means (economic power and normative power) and targets (individual states and international organizations) of diplomacy, they have one thing in common: Taiwan uses them as instruments to overcome its security environment crisis by effectively gaining the support of the international community against China, which is stronger in material capabilities but vulnerable when it comes to respecting international norms. Although the norms themselves, such as human rights, liberty, international cooperation, and common prosperity based on democracy and market economy, are put forward as the ultimate goal, Taiwan uses these norms as a concrete foreign policy means for its actual goal: ensuring the country's security interests. This is the main characteristic demonstrated by Taiwan's foreign policy as a middle power.

Table 7. Varieties of Middle Power Foreign Policy

\begin{tabular}{|c|c|c|c|}
\hline & & Diplom & eans \\
\hline & & Economic Power & Normative Power \\
\hline & States & $\begin{array}{l}\text { I } \\
\text { Cooptive Diplomacy }\end{array}$ & $\begin{array}{c}\text { II } \\
\text { Counter-Normative } \\
\text { Diplomacy }\end{array}$ \\
\hline & $\begin{array}{l}\text { International } \\
\text { Organizations }\end{array}$ & $\stackrel{\text { III }}{\text { Benefit Sharing Diplomacy }}$ & $\begin{array}{c}\text { IV } \\
\text { Universal Normative } \\
\text { Diplomacy }\end{array}$ \\
\hline
\end{tabular}

Taiwan's middle power diplomacy, which has evolved to take various forms, is encountering limitations and constraints at the internal and external levels. China views Taiwan's activities in expanding its international space as a means of achieving its independence. The mainland is fearful that as the island's global participation independent of the mainland continues to grow, Taiwan would use its increased space to push for de jure independence. The Chinese government believes that the use of "Taiwan" or the "Republic of China" suggests the existence of "Two Chinas" or "One China, One Taiwan" in the international community, demolishing its "One China” policy (Glaser 2013, 4-5). 
Taiwan's two achievements of democratization and economic development also constrain its foreign policy at the domestic level regarding how to manage relations with China. The DPP aims to establish a sovereign state based on a Taiwanese identity independent of China, whereas the KMT claims a uniform Chinese identity and a unification with China. These different ideas and policies for Taiwan's relations with China and the future of Taiwan have caused political and identity conflicts between the two parties and their supporters (Wang and Chang 2006, 377). However, Taiwan's democratization and new identity as a democratic state, as discussed, have led Taiwanese policy makers to pursue their policies under the restrictions arising not only from the dichotomy between the Chinese identity and the Taiwanese identity but also from complex policy situations.

The politics and the level of democracy in China influence Taiwan's politics and its foreign policy approaches. In a survey conducted in June 1990, about 42 percent of the 1,128 respondents said that they would support Taiwan's independence "if the Chinese Communists continue one-party dictatorship," whereas only 5 percent said they would support Taiwan's independence "if the Chinese Communists practice democracy and freedom” (Wachman 1994, 231). The effect of the political conditions in China on Taiwan's domestic politics was also shown during the Hong Kong protests in 2019. At the beginning of 2019, President Tsai's poll ratings were far less than that of Han Kuo-yu, the KMT's presidential candidate. ${ }^{1}$ However, a dramatic reversal occurred as the Hong Kong protests continued violently. In a survey conducted in August 2019, Tsai's poll ratings reached 51 percent, whereas Han's poll ratings remained at only 31 percent (Pan 2019). These results suggest that not only Taiwan's domestic democratization but also China's political circumstances have become new constraints that compel foreign policy makers in Taiwan to frame policies toward China by considering the changing political situation in China in terms of its democratic progress and then adopting appropriate measures.

\section{CROSS-STRAIT ECONOMIC RELATIONS AND THE ECONOMIC CONSTRAINTS OF DIPLOMACY}

Taiwan's economic development and deepening economic ties with China impose another constraint on Taiwan's policy makers. The economic relations between Taiwan and China have improved rapidly since the end of the Cold War

\footnotetext{
${ }^{1}$ China was suspected to intervene in Taiwanese politics and the presidential election of 2020 by offering incentives to Taiwanese businesses and support for President Tsai's political opponents, including the KMT (Myers and Horton 2020).
} 
and the spread of globalization. Despite the continuing military tension and conflict between the two countries, remarkable improvements have been achieved in the economic area through exchanges of capital, material, and human resources. As Table 8 illustrates, exports from Taiwan to China increased from US\$ 623 million in 1996 to US\$ 96,756 million in 2018, and Taiwan's imports from China increased from US $\$ 3,059$ million to US $\$ 53,783$ million during the same period. The amount of approved investment from Taiwan in China also abruptly increased from US\$1,229 million in 1996 to US\$14,616 million in 2010, and it amounted to US\$ 8,497 million in 2018 (National Development Council 2019, 24). Most importantly, Taiwan has tremendously expanded its trade surpluses with China over the past two decades, and China has become vital to Taiwan's economy because its export-driven economy relies on mainland business. About forty percent of Taiwan's exports go directly to Mainland China and Hong Kong (Glaser 2013, 3).

Table 8. Trade across the Taiwan Strait and Approved Investment in Mainland China

\begin{tabular}{|c|c|c|c|c|c|c|c|}
\hline \multirow[b]{3}{*}{ Year } & \multicolumn{5}{|c|}{ Trade across the Taiwan Strait } & \multirow{2}{*}{\multicolumn{2}{|c|}{$\begin{array}{l}\text { Approved Investment } \\
\text { in Mainland China }\end{array}$}} \\
\hline & \multicolumn{2}{|c|}{$\begin{array}{c}\text { Exports to } \\
\text { Mainland China }\end{array}$} & \multicolumn{2}{|c|}{$\begin{array}{l}\text { Imports from } \\
\text { Mainland China }\end{array}$} & \multirow[b]{2}{*}{$\begin{array}{c}\text { Balance } \\
\text { (US\$ million) }\end{array}$} & & \\
\hline & $\begin{array}{c}\text { Amount } \\
\text { (US\$ million) }\end{array}$ & $\begin{array}{l}\% \text { change } \\
\text { from } \\
\text { previous } \\
\text { year }\end{array}$ & $\begin{array}{c}\text { Amount } \\
\text { (US\$ million) }\end{array}$ & $\begin{array}{l}\text { \% change } \\
\text { from } \\
\text { previous } \\
\text { year }\end{array}$ & & $\begin{array}{c}\text { Number } \\
\text { of } \\
\text { Cases }\end{array}$ & $\begin{array}{c}\text { Amount } \\
\text { (US\$ million) }\end{array}$ \\
\hline 1996 & 623.4 & 65.5 & $3,059.9$ & -1.0 & $-2,436.5$ & 383 & $1,229.2$ \\
\hline 1998 & 914.9 & 46.0 & $4,113.9$ & 5.1 & $-3,199.0$ & 1,284 & $2,034.6$ \\
\hline 2000 & $4,391.5$ & 68.8 & $6,229.3$ & 37.6 & $-1,837.8$ & 840 & $2,607.1$ \\
\hline 2002 & $10,690.0$ & 112.9 & $8,041.3$ & 34.7 & $2,648.8$ & 3,116 & $6,723.1$ \\
\hline 2004 & $36,722.8$ & 58.2 & $16,891.5$ & 52.2 & $19,831.4$ & 2,004 & $6,940.7$ \\
\hline 2006 & $52,377.1$ & 18.9 & $24,909.0$ & 23.6 & $27,468.2$ & 1,090 & $7,642.3$ \\
\hline 2008 & $67,515.8$ & 7.3 & $31,579.7$ & 11.9 & $35,936.2$ & 643 & $10,691.4$ \\
\hline 2010 & $77,949.5$ & 42.1 & $36,255.2$ & 47.7 & $41,694.4$ & 914 & $14,617.9$ \\
\hline 2012 & $82,666.2$ & -3.0 & $41,431.4$ & -6.0 & $41,234.8$ & 636 & $12,792.1$ \\
\hline 2014 & $84,738.1$ & 0.7 & $49,254.4$ & 13.6 & $35,483.7$ & 497 & $10,276.6$ \\
\hline 2016 & $73,878.9$ & 0.6 & $43,990.8$ & -2.8 & $29,888.1$ & 323 & $9,670.7$ \\
\hline 2018 & $96,756.4$ & 8.7 & $53,783.5$ & 7.5 & $42,972.9$ & 726 & $8,497.7$ \\
\hline
\end{tabular}

Source: National Development Council, Republic of China (2019), p. 24.

As Taiwan's economy is becoming increasingly interconnected with and dependent on China in terms of trade and exchanges, Taiwanese policy makers face more complex domestic policy constraints regarding economic policies toward China. Policy makers can no longer be free from the political pressure 
of voters who demand continuous economic growth and more economic benefits based on a closer relationship with China. On a different note, strong voices are expressing concern that the expansion and intensification of economic ties with China will increase Taiwan's dependence on and vulnerability to China in the face of the continuing strong Chinese military threat (Chi 2016, 67).

Differences and conflicts in the political approach to Taiwan's economic policy have emerged in this context of intertwining security and economies. The KMT has espoused its approach to economic policies and strategies for a more friendly relationship with China, whereas the DPP has been much more circumspect in its embrace of trade liberalization across the strait. For example, in the 2008 legislative elections, the KMT advocated economic growth through trade expansion with China. In the 2012 legislative elections, the KMT pledged to achieve sustainable economic growth through the Economic Cooperation Framework Agreement (ECFA) with China. However, the DPP criticized the KMT's pledge, arguing that the expansion of trade relations with China would not only increase Taiwan's economic dependence on China and heighten its security vulnerability but also widen wealth inequality at the domestic level (Fuller 2014, 91-96).

The KMT, which won both elections, signed the ECFA with China and entered into a stage of full-fledged expansion of trade relations with China. President $\mathrm{Ma}$ of the KMT pursued a deeper economic integration across the strait during his two terms. By contrast, President Tsai of the DPP implemented quite a different economic policy toward China since she took presidential office in 2016. The Tsai administration has actively tried to reduce the country's economic dependence on China by seeking to increase trade and business opportunities with Southeast Asian nations and improving the country's partnerships with Japan, Australia, and Europe (Teng 2019a). Tsai's government launched the New Southbound Policy in mid-2016 to reduce Taiwan's dependence on China by increasing cooperation with Southeast Asian and South Asian countries as well as New Zealand and Australia (Lim and Lee 2018). ${ }^{2}$ In retaliation to the Tsai government, the Chinese government not only intensified its military pressure and campaign to isolate Taiwan diplomatically but also tried to hurt Taiwan's economy by restricting economic and cultural ties, including tourist trips (Hille 2019). The deterioration of cross-strait relations coupled with economic stagnation culminated in the political crisis of DPP government. In November 2018, Tsai's

2 The primary goal of the New Southbound Policy is to reduce Taiwan's economic dependency on mainland China or a single market. Under this policy the Taiwanese government intends to work with countries in the region and around the world to deepen and broaden Taiwan's presence in South and Southeast Asia (Marston and Bush 2018). 
DPP was defeated in the local elections by the KMT, which advocated a pro-Chinese foreign policy (Rigger 2019).

These conflicts in Taiwan's economic policy toward China imply that policy makers in Taiwan face new policy constraints not only internally through the voices of contending domestic interest groups but also externally through the pressure from China, on which the Taiwanese economy is becoming increasingly dependent. Democratization and economic development, both of which have provided powerful diplomatic means to the Taiwanese government, constrain the autonomy of Taiwan's foreign policy as a middle power.

\section{CONCLUSION}

Taking Taiwan as an example, this study investigated how a country emerges as a middle power using the anchors of democratization and economic development in a security environment marked by a strong and constant military threat. The research likewise identified the characteristics of the foreign policy implemented by Taiwan as an emerging middle power by focusing on the policy instruments available to and the constraints faced by its policy makers. Diverging from the conventional standpoint that a challenging security environment in the form of a strong external threat adversely affects political and economic development, Taiwan instead prevailed in its transformation into a middle power, thereby demonstrating that hazards to security can also favorably influence democratization and economic progress. Taiwan's foreign policy weapons have been brushed by its perpetual enemy-China. By probing into Taiwan's foreign policy as a middle power, this study uncovered that economic growth and political development advance the use of material capabilities and norms as instruments for pursuing diverse foreign policy goals in international politics.

Notwithstanding the fact that economic development and democratization create the momentum for a state to rise as a middle power, they also limit a state's autonomy and impose new domestic and international constraints on policy makers. These problems exposes a middle power to the dual influence of or interaction between internal and external constraints. Taiwan's domestic democratization and China's political problems, such as the Tiananmen Square protests in 1989 and the Hong Kong demonstrations in 2019, have arisen as recent deterrents that compel foreign policy makers in Taiwan to frame policies that enable the country to deal with China. These policies are grounded in a consideration of the changes to China's democratic progress. Policy makers in 
Taiwan also face new internal policy constraints from domestic interest groups, whose dissension is related to Taiwan's economic policy toward China, and external restrictions in the form of pressure from China, on which the Taiwanese economy increasingly depends. Democratization and economic development have served as powerful diplomatic measures for the Taiwanese government, but they have also constrained the autonomy of Taiwan's foreign policy as a middle power.

The bounded autonomy in Taiwan illustrates that pinpointing the characteristics of foreign policy and understanding the formation of a middle power necessitate exploring relevant domestic and international attributes and the interactions between these aspects. The country's foreign policy is influenced by various factors, such as the level of economic development and democratization in the nation, the political and economic characteristics of competing countries, and the material and normative characteristics of the international community. Taiwan's foreign policy is especially influenced by countries and international organizations that offer foreign policy elements targeted by the Taiwanese, such as diplomatic recognition and accession. Foreign policy makers are inhibited by arising domestic challenges and by the structure and norms of international politics. Nonetheless, the efforts and achievements of policy makers to expand and strengthen the instruments that are useful for implementing foreign policy (e.g., materials and norms) indicate the existence of an autonomy that paves the way for broadening the spectrum of foreign policy instruments wielded by Taiwan and the targets that it aspires to acquire from the international society.

Alongside bounded autonomy, which is a universal characteristic of a middle power's foreign policy, Taiwan is peculiar in that it actively uses norms and values to pursue national security interests. This peculiarity is attributable to the special conditions facing Taiwan, characterized by separation from China and an incomplete sovereignty that deprives it of the recognition and approval of the international community, even as it meets all the requirements of a sovereign state. Comparison with other middle power countries would provide a valuable opportunity to examine the universality and particularity of middle power diplomacy. For example, South Korea is contending with a similar international security environment typified by national division and strong external threats. Unlike the circumstances surrounding Taiwan, however, South Korea's peculiar condition is its perception of incomplete internal sovereignty for want of territorial unification, albeit it has already obtained objective recognition and approval from the international community as a sovereign state. Exploring the foreign policy of a middle power that faces different domestic and international 
situations can show patterns that differ from those of Taiwan, which uses material capabilities and norms as political instruments for securing official international approval and recognition. A case study on Taiwan can be a starting point for understanding the universality and specificity of the foreign policy implemented by middle powers. Further comparative case studies should also be devoted to the commonalities and differences among the foreign policies of middle powers and the causes and conditions associated with such commonalities and differences.

\section{REFERENCES}

Asian Development Bank. 2019. Fact Sheet. Accessed at https://www.adb.org/ publications/series/fact-sheets (January 7, 2020).

Aspinwall, Nick. 2019. "Taiwan Picks Up International Support After Being Barred from World Health Assembly." The Diplomat (May 10).

Bureau de Genève, Délégation Culturelle et Économique de Taipei. 2019. "MOFA Strongly Condemns China's Unjustifiable Interference with Taiwan's Participation in the WHA." (May 6). Accessed at https://www.roc-taiwan. org/chgva_fr/post/1226.html (December 31, 2019).

Chan, Steve. 1988. "Defense Burden and Economic Growth: Unraveling the Taiwanese Enigma.” The American Political Science Review 82(3), 913920.

Chao, Linda, and Ramon H. Myers. 1998. The First Chinese Democracy: Political Life in the Republic of China on Taiwan. Baltimore: The Johns Hopkins University Press.

Chen, Frank. 2019. “Taiwan Fears Losing 'Statehood' as Allies Leave.” Asia Times (October 16).

Chen, Dean P. 2017. US-China Rivalry and Taiwan's Mainland Policy: Security, Nationalism, and the 1992 Consensus. Cham: Palgrave Macmillan.

Chen, Lung-Chu. 2016. The U.S.-Taiwan-China Relationship in International Law and Policy. Oxford: Oxford University Press.

Chi, Eunju. 2015. "Kyŏngjeisyu, chŏngdang chaep’yŏnsŏng, kŭrigo chunggukyosor: Taemanŭi sarye [Economic Issues, Party Realignment, and China Factor: The Case of Taiwan]." The Korean Journal of International Studies 55(1), 65-99.

Cooper, Andrew F., Richard Higgott, and Kim Nossal. 1993. Relocating Middle Powers: Australia and Canada in a Changing World Order. Vancouver: 
UBC Press.

Courtenay, Philip. 2006. "Four Decades Participation in ADB." Taiwan Today

(December 29).

Deger, Saadet, and Ron Smith, 1983. "Military Expenditure and Growth in Less Developed Countries." The Journal of Conflict Resolution 27(2), 335-353. deLisle, Jacques. 2009. "Taiwan in the World Health Assembly: A Victory, with Limits.” Brookings East Asia commentary, May 13.

. 2014. "Taiwan and Soft Power: Contending with China and Seeking Security." In Jean-Pierre Cabestan and Jacques deLisle eds., Political Changes in Taiwan under Ma Ying-jeou: Partisan Conflict, Policy Choices, External Constraints and Security Challenges. London: Routledge.

Downing, Brian. 1988. "Constitutionalism, Warfare, and Political Change in Early Modern Europe." Theory and Society 17, 7-56.

Fuller, Douglas B. 2014. "ECFA's Empty Promise and Hollow Threat." In Jean-Pierre Cabestan and Jacques deLisle eds., Political Changes in Taiwan under Ma Ying-jeou: Partisan Conflict, Policy Choices, External Constraints and Security Challenges. London: Routledge.

Glaser, Bonnie S. 2013. Taiwan's Greater Participation in the International Community. New York: Roman \& Littlefield, Center for Strategic \& International Studies.

Hille, Kathrin. 2019. “Taiwan's Tsai Ing-wen Sends Message of Defiance to Beijing," Financial Times (October 10).

Hintze, Otto. 1975. "Military Organization and the Organization of the State." In Felix Gilbert (ed). The Historical Essay of Otto Hintze. Oxford: Oxford University Press.

Hiscox, Michael J. 2001. "Class versus Industry Cleavages: Inter-Industry Factor Mobility and the Politics of Trade." International Organization 55(1), 1-46.

Horowitz, Shale, and Alexander C. Tan. 2007. "Rising China versus Estranged

Taiwan.” In Shale Horowitz, Uk Heo, and Alexander C. Tan eds., Identity and Change in East Asian Conflicts: The Cases of China, Taiwan, and the Koreas. New York: Palgrave Macmillan.

Horton, Chris. 2017. "APEC: Taiwan's Most Important International Forum.” The News Lens (February 15).

Huang, Kwei-Bo. 2019. "Taiwan Blocked: WHA an Indicator of Sour Cross-Strait Relations.” Korea Times (May 25).

Huang, Peter. 2009. "A Breakthrough in Human Rights.” Taipei Times (April 8), 8. Hughes, Christopher. 1997. Taiwan and Chinese Nationalism: National Identity 
and Status in International Society. London: Routledge.

International Institute for Strategic Studies (IISS). 1987-2017. The Military Balance. London: Institute for Strategic Studies.

Johnson, Chalmers A. 1982. MITI and the Japanese Miracle: The Growth of Industrial Policy, 1925-1975. Stanford: Stanford University Press.

Katzenstein, Peter J. 1996. Cultural Norms and National Security: Police and Military in Postwar Japan. Ithaca: Cornell University Press.

Keohane, Robert. 1984. After Hegemony: Cooperation and Discord in the World Political Economy. Princeton: Princeton University Press.

Lasswell, Harold. 1997. Essays on the Garrison State. New Brunswick: Transaction Publishers.

Lawrence, Susan V. and Way M. Morrison. 2017. "Taiwan: Issues for Congress,” Congressional Research Service (CRS) Report, 7-5700 (October 30).

Lee, Wei-Chin. 1993. “Taiwan's Foreign Aid Policy.” Asian Affairs: An American Review 20(1), 43-62.

Lim, Emerson and Lee Hsin-Yin. 2018. "Taiwan Seeks Further Cooperation with Asian Development Bank." Focus Taiwan (May 5).

Lin, Amber. 2018. "From GATT to WTO, Taiwan's Global Chess Match." Common Wealth Magazine (November 27).

Lin, Chia-nan. 2019. "Taiwan Seeking 'Dignified' Ebola Contribution: MOFA.” Taipei Times (July 24), p. 1.

Lin, Syaru Shirley. 2016. Taiwan's China Dilemma: Contested Identities and Multiple Interests in Taiwan's Cross-Strait Policy. Stanford: Stanford University Press.

Lo, Chang-fa. 2011. "Taiwan: External Influences Mixed with Traditional Elements to Form its Unique Legal System.” In E. Ann Black and Gary F. Bell eds., Law and Legal Institutions of Asia: Traditions, Adaptations and Innovations. Cambridge: Cambridge University Press.

Lyons, Kate. 2019. "Taiwan Loses Second ally in a Week as Kiribati Switches to China." The Guardian (September 20).

Marshall, Monty G., and Ted Robert Gurr, Polity IV Project: Political Regime Characteristics and Transitions, 1800-2013 (Center for Systemic Peace). Accessed at https://www.systemicpeace.org/polity/polity4.htm (May 20, 2019).

Martin, Jeffrey. 2014. "The Confucian Ethic and the Spirit of East Asian Police: A Comparative Study in the Ideology of Democratic Policing." Crime, Law, and Social Change 61, 461-490.

Martin, Jeffrey, Charles K. Chang, and Sandy Y. Yeh. 2007. "Police Professionalism in Taiwan China, 1953-1993.” The 7th AAPS Annual 
Conference Paper in Thailand, 228-239.

Marston, Hunter, and Richard C. Bush. 2018. "Taiwan's Engagement with Southeast Asia Is Making Progress under the New Southbound Policy," Taiwan-U.S. quarterly Analysis of Brookings Institution (July 30).

Mattlin, Mikael. 2011. Politicized Society: The Long Shadow of Taiwan's One-Party Legacy. Copenhagen: Nordic Institute of Asian Studies.

McBeath, Gerald. 1979. "Political Training and Attitudes of Taiwan's Police Recruits.” International Journal of Comparative and Applied Criminal Justice 3(2), 157-166.

Ministry of Foreign Affairs. 2009. White Paper on Foreign Aid Policy. Republic of China, Taiwan.

Ministry of Foreign Affairs, the Republic of China. "MOFA Regrets WHO's Inability to Reach Appropriate Arrangement for Taiwan's Donation to Ebola Prevention Efforts." Accessed at https://www.taiwanembassy.org /nr_en/post/1715.html (December 31, 2019).

Myers, Steven and Chris Horton. 2019. "As Taiwan Loses Influence, China Gains Ground in Race with U.S." The New York Times (September 20). . 2020. "China Looms over Taiwan's Election, Giving a Boost to the Incumbent." The New York Times (January 8).

National Development Council. Taiwan Statistical Data Book, 2012-2019. Accessed at https://www.ndc.gov.tw/en/News.aspx?n=607ED34345641 980\&sms=B8A915763E3684AC (December 31, 2019).

Nolan, Janne E. 1986. Military Industry in Taiwan and South Korea. New York: Palgrave Macmillan.

Olson, Elizabeth. 2001. “Taiwan Is Cleared for Membership in WTO.” The New York Times (September 19).

Pan, Jason. 2019. “Tsai Boosts Support, Approval Rating: Survey.” Taipei Times (August, 08).

Pempel, T. J. 1999. "The Developmental Regime in a Changing World Economy." In Meredith Woo-Cumings ed., The Developmental State. Ithaca, New York: Cornell University Press.

Peng, Ming-min. 1971. "Political Offences in Taiwan: Laws and Problems." The China Quarterly 47, 471-493.

Pepinsky, Thomas B. 2008. "Capital Mobility and Coalitional Politics: Authoritarian Regimes and Economic Adjustment in Southeast Asia.” World Politics60, 438-474.

Rich, Timothy. 2019. "Does It Matter If Taiwan Loses Formal Recognition?" Taiwan News (October 13).

Rich, Timothy, and Andi Dahmer. 2018. "Does Taiwan Need International 
Recognition?” Asia Dialogue (March 12).

Rigger, Shelley. 2014. "Political Parties and Identity Politics in Taiwan." In Larry Diamond and Gi-Wook Shin eds., New Challenges for Maturing Democracies in Korea and Taiwan. Stanford: Stanford University Press. . 2019. "Why Taiwan Is Watching Hong Kong Very Closely." The Washington Post (September 4).

Robertson, Jeffrey. 2017. "Middle-Power Definitions: Confusion Reigns Supreme," Australian Journal of International Affairs 71(4), 355-370.

Rogin, Hosh. 2019. "The United States Must Help Taiwan Resist Chinese Dominance." The Washington Post (March 28).

Rogowski, Ronald. 1989. Commerce and Coalitions: How Trade Affects Domestic Political Alignments. Princeton: Princeton University Press.

Smith, Nicola. 2017. "China Is Trying to Bar Taiwan from the World's Top Health Summit." Time (May 5).

Taiwan Today. 2011. "Taiwan to Release Human Rights Report in February" (December 9).

. 2012. "A Decade of Taiwan WTO Membership" (January 23).

. 2013. "Ma Remarks on Anniversary of June 4 Incident" (June 5).

. 2015. "ROC Works to Implement International Covenants" (December 21). . 2019. "MOFA Condemns China for Blocking Taiwan's WHA Participation" (May 7).

Teng, Pei-ju. 2018. “Taiwan Suspends Plan for US\$1 million Donation to WHO.” Taiwan News (December 24).

. 2019a. "Less Dependence on China Means Stable Growth for Taiwan's Economy: President Tsai." Taiwan News (May 20).

. 2019b. "Support for Taiwan Gathers Momentum at WHA." Taiwan News (May 22).

Tiezzi, Shannon. 2014. "Taiwan and the Fight Against Ebola." The Diplomat (December 9).

Tilly, Charles. 1990. Coercion, Capital, and European States, AD 990-1990. Oxford: Basil Blackwell.

Tubilewicz, Czeslaw. 2004. "Breaking the Ice: The Origins of Taiwan's Economic Diplomacy towards the Soviet Union and Its European Allies." Europe-Asia Studies 56(6), 891-906.

Wachman, Alan M. 1994. Taiwan: National Identity and Democratization. London: Routledge.

Wade, Robert. 1990. Governing the Market: Economic Theory and the Role of Government in East Asian Industrialization. Princeton: Princeton University Press. 
Waltz, Kenneth N. 1993. "The Emerging Structure of International Politics." International Security 18(2), 44-79.

Wang, Flora. 2009. "Legislature Ratifies UN Rights Treaties.” Taipei Times (April 2), 3.

Wang, Yu San. 1990. “Foundation of the Republic of China's Foreign Policy.” In Yu San Wang (ed.). Foreign Policy of the Republic of China on Taiwan. New York: Praeger.

Wang, T.Y., and G. Andy Chang. 2006. "External Threats and Political Tolerance in Taiwan.” Political Research Quarterly59(3), 377-388.

Wen, Philip. 2019. "Taiwan Loses Another Diplomatic Tie, as China Continues Isolation Campaign.” Wall Street Journal (September 20).

Winkler, Sigrid. 2014. "Taiwan in International Organizations: New Road Ahead or Dead-end?" In Jean-Pierre Cabestan and Jacques deLisle eds., Political Changes in Taiwan under Ma Ying-jeou: Partisan Conflict, Policy Choices, External Constraints and Security Challenges. London: Routledge.

Woo, Jongseok. 2011. Security Challenges and Military Politics in East Asia: From State Building to Post-Democratization. New York: Continuum.

Yang, Chun-hui, and Jonathan Chin. 2019. "Tsai Touts Democracy, Calls for Support.” Taipei Times (July 14), 1.

Yeh, Su-ping and Emerson Lim. 2019. "Tsai Details Two Tasks for Taiwan APEC Summit Representative." Focus Taiwan (October 14).

[Received Jan 12, 2020; Revised Mar 23, 2020; Accepted Apr 1, 2020] 